\section{Evaluation of beef in purified sea water: microbiological and chemical-physical aspects}

\author{
Simone Stella, Cristian Bernardi, \\ Davide Timaco, Erica Tirloni
}

Department of Veterinary Medicine and Animal Sciences, University of Milan, Lodi, Italy

\begin{abstract}
In this study the influence of the maintenance of beef (Bavarian heifer meat submitted to dry aging for 1 month) in purified sea water was evaluated considering microbiological and physical-chemical parameters. The treated samples were perforated on their upper and lower surfaces, subsequently placed in sterile plastic containers, and covered with purified sea water while the control samples were wrapped in a plastic film; all the samples were stored at $2^{\circ} \mathrm{C}$ and sample analyses were performed on the day of receipt ( $\mathrm{t} 0$ ) and after five (t5), seven ( $\mathrm{t} 7$ ) and ten (t10) days of storage. The initial bacterial population was close to $6 \log$ $\mathrm{CFU} / \mathrm{g}$, as expected in meat subjected to a long ageing. After 5 and 10 days of storage the treated samples showed significantly lower counts for most parameters (Total Bacterial Count, Enterobacteriaceae, Lactic Acid Bacteria and Pseudomonas spp.) if compared to the control samples. Halotolerant bacteria, yeasts and moulds showed no differences between the two series. During the test, the exposed surface of treated meat samples underwent a partial protein denaturation. Analyses show a moderate acidification of the meat during the first part of storage (from t0 to t5), followed by a substantial stabilization in the second part of the trial. The meat maintained in purified sea water acquired a significantly and constantly higher water retention due to the absorption of salt by the meat. No significant difference was detected in terms of tenderness between the two series.
\end{abstract}

\section{Introduction}

General beef palatability is commonly related to three primary attributes that are tenderness, juiciness, and flavour (Smith and Carpenter, 1974). In the last decades, many studies investigated the impact of animal production factors (such as breed, diet, age, stress) and of meat production and processing (such as aging, chilling...) on these attributes (Koohmaraie et al., 2002).
Tenderness resulted as the most important characteristic that influence consumers' opinion on beef and has an impact on the general eating satisfaction and decisions to rebuy (Shackelford et al., 2001). Shackelford et al. (2001), in the same study, stated that $50 \%$ of consumers declared a willing to pay $\$ 1.10 / \mathrm{kg}$ extra for the assurance of tenderness. Also, Boleman et al. (1997) and Lusk et al. (1999; 2001) found that consumers were willing to pay an extra price for a guaranteed tender beef product. Thus, an improvement in tenderness would increase the final product value (Brooks et al., 2000). Among the numerous aspects influencing beef tenderness, ageing conditions is crucial, thanks to the activity of endogenous peptidases (Koohmaraie, 1996). Also, other parameters may be modified by the ageing process: muscle $\mathrm{pH}$ gradually increases during this process, due to the proteolytic reactions, as well as the meat water holding capacity that increases, due to the formation of an open structure with a higher accessibility of hydrophilic sites. Moreover, meat colour modifies during ageing (Cheng and Sun, 2008; Lawrie, 1974).

This study aimed to evaluate the influence of the maintenance of aged beef in purified sea water, analysing how this procedure could affect the microbiological and physical-chemical characteristics of the meat.

\section{Materials and methods}

\section{Meat and packaging conditions}

A total of 16 samples of adult bovine meat were considered. Meat was obtained from Bavarian heifer carcasses submitted to dry aging for 1 month; "T-bone" steaks (Longissimus dorsi and Psoas major muscles) were taken and assigned to "treated" or "control" series. The treated samples were perforated in partial thickness, on their upper and lower surfaces, by stainless steel needles ( $3 \mathrm{~mm}$-thick), previously submitted to ethanol disinfection. Then, the samples were placed in pairs in plastic containers with lids and covered with purified sea water $(38 \%$ of $\mathrm{NaCl})$ for 10 days; the samples were then stored at a temperature of $2{ }^{\circ} \mathrm{C}$. The control samples were wrapped in a plastic film, to limit surface drying, and kept at the same temperature as the treated meat for 10 days. The analyses were performed on the day of receipt ( $\mathrm{t} 0$ ) and, subsequently, after five (t5), seven (t7) and ten (t10) days of storage. For each pair of samples, one was used for microbiological and chemical-physical analyses to be carried out
Correspondence: Erica Tirloni, Department of Veterinary Medicine and Animal Sciences, University of Milan, Via dell'Università 6, IT26900, Lodi, Italy. Tel: +39.02 .50334333$

E-mail: erica.tirloni@unimi.it

Key words: Meat ageing, Artificial Sea water, Beef quality.

Contributions: The authors contributed equally.

Conflict of interest: The authors declare no conflict of interest.

Funding: None.

Received for publication: 12 August 2021. Accepted for publication: 10 January 2022.

This work is licensed under a Creative Commons Attribution-NonCommercial 4.0 International License (CC BY-NC 4.0).

CCopyright: the Author(s), 2022

Licensee PAGEPress, Italy

Italian Journal of Food Safety 2022; 11:10034

doi:10.4081/ijfs.2022.10034

directly on the raw sample, while the other was used for the analyses to be carried out on the cooked product.

\section{Evolution of microbial populations during the shelf life}

For microbial counts, $10 \mathrm{~g}$ of each sample, taken form the surface of the steak (maximum thickness of $5 \mathrm{~mm}$ ) were homogenized in $90 \mathrm{~mL}$ of a diluent solution $(0.85 \% \mathrm{NaCl}$ and $0.1 \%$ tryptone), and serial 10 -fold dilutions were prepared. Total viable count (TVC) was determined according to the ISO 4833 (ISO, 2013) method. Lactic acid bacteria (LAB) were enumerated according to ISO 15214 (ISO, 1998) method. The number of Enterobacteriaceae was determined by the ISO21528-2 (ISO, 2017) method. Pseudomonas spp. were determined onto PSA added with CFC supplement, the incubated at $30^{\circ} \mathrm{C}$ for $48 \mathrm{~h}$. Yeasts and moulds were enumerated according to ISO 21527 1:2008 (ISO, 2008). Count of halotolerant bacteria (Tryptone Soy Agar medium $+3.5 \% \mathrm{NaCl}$, incubation at $30^{\circ} \mathrm{C}$ for $96 \mathrm{~h}$ ), was also performed in order to detect the specific microflora that could potentially develop following the storage of the meat of the treated series in a relatively high salinity environment. Microbiological analyses were performed in duplicate.

\section{Chemical-physical analyses}

\section{$p H$}

The $\mathrm{pH}$ of the products was determined by a pHmeter (Ghiaroni, mod. XS pH 6, 
Buccinasco, Italy), equipped with an infission probe; $\mathrm{pH}$ determination was performed in duplicate.

\section{Moisture and salt concentration}

The samples underwent to the following determinations: moisture content (AOAC 1990), and salt content as total chlorides (Pearson, 1973). Water Phase Salt content (WPS) was then calculated with the formula WPS $=\%$ salt $(\% \text { salt }+\% \text { moisture })^{-1} * 100$ (Huss et al., 1995). All the determinations were performed in duplicate.

\section{Water holding capacity}

The water holding capacity was evaluated by a compression method on filter paper (Grau and Hamm, 1956). The result was expressed as the ratio between the area occupied by compressed meat and that of the extracted liquid.

\section{Colour parameters}

The measurement of colour parameters was performed after a blooming of $45 \mathrm{~min}$ oxygenation; after calibration using a standard white plate, the Chromameter instrument (Minolta Chroma Meter CR-400) was positioned perpendicular to the slice surface. Measurements were performed on the steak surfaces, 45 min after opening, in order to allow blooming (deoxymyoglobin oxygenation). During this time, beef slices were put into Polysilk bags (Baglight), in order to permit the contact with air but avoiding superficial drying and maintained at refrigeration temperature $\left(2 \pm 1{ }^{\circ} \mathrm{C}\right)$ to maintain optimal storage condition. The CIE L*, a* and $b^{*}$ values (CIE, 1976) which describe the intensity of whiteness/brightness, red colour $\left(a^{*}>0\right)$ and yellowness $\left(b^{*}>0\right)$, respectively, were taken at six locations on the upper layer of each sample. The average of 6 such measurements was expressed as the final value. The hue angle $(\mathrm{h})$ was calculated as $\mathrm{h}=\arctan$ $\left(\mathrm{b} * / \mathrm{a}^{*}\right) * 57.32$, and Chroma was calculated as $\mathrm{Ch}=\sqrt{ }\left(\mathrm{a}^{* 2}+\mathrm{b}^{* 2}\right)$.

\section{Cooking loss}

For cooking loss determination, the steaks were weighed and cooked following the method by Honikel (1998) with minor modifications. Briefly, the slices were put into $190 \times 300 \mathrm{~mm}, 65 \square \mu \mathrm{m}$ thick Polysilk bags (thermal resistance: $-40 \pm 80^{\circ} \mathrm{C}$; Baglight, Interscience, Saint Nom, France) and placed in a thermostatic water bath at $75^{\circ} \mathrm{C}$, until they reached a targeted peak internal temperature of $72^{\circ} \mathrm{C}$. Temperature measurements were obtained by a thermometer (735-2, Testo, Settimo Milanese, Italy) equipped with a probe (PT $\square 100$, Testo) inserted into the core of each steak. When the end-point temperature was reached, bags were removed from the water bath and cooled under tap water (for 15-20', until they reached a temperature about $20^{\circ} \mathrm{C}$ ), and then submitted to overnight air refrigeration, reaching a temperature of $4^{\circ} \mathrm{C}$. The ratio between the weight measured before and after cooking was calculated; for rib eye steaks, the calculation was made on deboned samples, to reduce the dampening effect of the bone weight.

\section{Warner-Bratzler shear force}

Warner-Bratzler shear force (WBSF) was measured as described previously (Wheeler et al., 1999), by an Instron Universal Testing Machine (model 5542, Instron Engineering Corp., Canton, MA; blade speed $=200 \mathrm{~mm} / \mathrm{min}$ ); the analysis was performed on six shares $(1.27 \mathrm{~cm}$ in diameter) from each sample. The shares were cut parallel to the longitudinal orientation of muscle fibres; the peak shear force was measured (Warner $\square$ Bratzler blade speed $200 \mathrm{~mm} / \mathrm{min}$ ), and mean values were recorded.

\section{TVBN}

Total volatile basic nitrogen (TVBN; Reg. (EC) N. 2074/2005; European Commission, 2005) was determined on each series in duplicate after sampling for microbiological analyses.

\section{Statistical analysis}

The data were submitted to statistical analysis (one-way ANOVA) by SAS/stat package version 8.0 (SAS Inst. Inc., Cary, USA); a comparison was made among the sample series (treated $v s$ control) and ageing times. A significance threshold of $\mathrm{P}=0.05$ was considered.

\section{Results and discussion}

\section{Microbiological analyses}

Microbiological results are reported in Table 1. Concentrations of total viable count at t0 were close to $6 \log \mathrm{CFU} / \mathrm{g}$; these counts, commonly found in aged meats at the beginning of shelf-life (Kilgannon et al., 2019), showed a significant increase from t0 to 5 ( $<<0.01)$, followed by a stable trend, without significant further modifications. Significantly lower values were found in the samples maintained in seawater if compared to control $(\mathrm{P}<0.05)$, in the whole period. Lactic Acid Bacteria showed a very limited and slight increase from t0 (below $4 \mathrm{log}$ $\mathrm{CFU} / \mathrm{g}$ ) till the end of the trial, with significantly lower values found in the samples maintained in seawater if compared to control $(\mathrm{P}<0.05)$; the behaviour of Lactic Acid Bacteria on meat surface is strongly influenced by the environmental conditions, such as atmosphere composition and moisture (Da Silva Bernardo et al., 2020), but

Table 1. Results obtianed from microbiological analyses.

\begin{tabular}{|c|c|c|c|c|c|}
\hline & & t0 & t5 & t7 & $\mathrm{t} 10$ \\
\hline TVC & $\begin{array}{l}\mathrm{T}^{\mathrm{b}} \\
\mathrm{C}^{\mathrm{a}}\end{array}$ & $\begin{array}{l}5.82 \pm 0.25 \\
5.82 \pm 0.25\end{array}$ & $\begin{array}{l}7.55^{\mathrm{B}} \pm 0.12 \\
8.53^{\mathrm{A}} \pm 0.12\end{array}$ & $\begin{array}{l}7.68 \pm 0.01 \\
8.45 \pm 0.59\end{array}$ & $\begin{array}{l}7.24^{\mathrm{B}} \pm 0.27 \\
8.94^{\mathrm{A}} \pm 0.41\end{array}$ \\
\hline Pseudomonas spp. & $\begin{array}{l}\mathrm{T}^{\mathrm{b}} \\
\mathrm{C}^{\mathrm{a}}\end{array}$ & $\begin{array}{l}5.60 \pm 0.01 \\
5.60 \pm 0.01\end{array}$ & $\begin{array}{l}7.18^{\mathrm{B}} \pm 0.26 \\
8.51^{\mathrm{A}} \pm 0.36\end{array}$ & $\begin{array}{l}7.32^{\mathrm{B}} \pm 0.06 \\
8.29^{\mathrm{A}} \pm 0.20\end{array}$ & $\begin{array}{l}6.97^{\mathrm{b}} \pm 0.03 \\
8.47^{\mathrm{a}} \pm 0.58\end{array}$ \\
\hline Enterobacteriaceae & $\begin{array}{l}\mathrm{Tb} \\
\mathrm{C}^{\mathrm{a}}\end{array}$ & $\begin{array}{l}<2.00 \\
<2.00\end{array}$ & $\begin{array}{l}5.11^{\mathrm{B}} \pm 0.29 \\
6.10 \mathrm{~A} \pm 0.22\end{array}$ & $\begin{array}{l}5.00 \pm 0.63 \\
5.82 \pm 0.50\end{array}$ & $\begin{array}{l}4.95^{\mathrm{B}} \pm 0.01 \\
6.34^{\mathrm{A}} \pm 0.23\end{array}$ \\
\hline $\mathrm{LAB}$ & $\begin{array}{l}\mathrm{T}^{\mathrm{b}} \\
\mathrm{C}^{\mathrm{a}}\end{array}$ & $\begin{array}{l}3.87 \pm 0.33 \\
3.87 \pm 0.33\end{array}$ & $\begin{array}{l}4.63 \pm 0.13 \\
5.05 \pm 0.38\end{array}$ & $\begin{array}{l}4.76 \mathrm{~B} \pm 0.14 \\
5.40 \mathrm{~A} \pm 0.08\end{array}$ & $\begin{array}{l}4.00^{\mathrm{B}} \pm 0.01 \\
4.69^{\mathrm{A}} \pm 0.09\end{array}$ \\
\hline Halotolerant bacteria & $\begin{array}{l}\mathrm{T} \\
\mathrm{C}\end{array}$ & $\begin{array}{l}5.15 \pm 0.14 \\
5.15 \pm 0.14\end{array}$ & $\begin{array}{l}7.53 \pm 0.43 \\
7.97 \pm 0.85\end{array}$ & $\begin{array}{l}7.89 \pm 0.26 \\
8.27 \pm 0.17\end{array}$ & $\begin{array}{l}7.30 \pm 0.43 \\
7.40 \pm 0.46\end{array}$ \\
\hline Yeasts & $\begin{array}{l}\mathrm{T} \\
\mathrm{C}\end{array}$ & $\begin{array}{l}3.85 \pm 0.15 \\
3.85 \pm 0.15\end{array}$ & $\begin{array}{l}4.55 \pm 0.21 \\
4.28 \pm 0.34\end{array}$ & $\begin{array}{l}4.98 \pm 0.43 \\
4.58 \pm 0.53\end{array}$ & $\begin{array}{l}4.16 \pm 0.28 \\
4.87 \pm 0.50\end{array}$ \\
\hline Moulds & $\begin{array}{l}\mathrm{T} \\
\mathrm{C}\end{array}$ & $\begin{array}{l}3.46 \pm 0.41 \\
3.46 \pm 0.41\end{array}$ & $\begin{array}{l}3.43 \pm 0.52 \\
2.46 \pm 0.41\end{array}$ & $\begin{array}{l}<3.00 \\
<3.00\end{array}$ & $\begin{array}{l}<3.00 \\
<3.00\end{array}$ \\
\hline
\end{tabular}

Superscript letters indicate a statistically significant difference between treated and control samples in the whole period (first column) or in the single sampling sessions (subsequent columns): A, significant difference $(\mathrm{P}<0.01)$; ${ }^{a, b}$ significant difference $(\mathrm{P}<0.05)$. 
also the salt concentration could exert an inhibitory effect. Considering Pseudomonas spp., count at t0 was on average equal to $5.6 \log \mathrm{CFU} / \mathrm{g}$; the relative high prevalence of Pseudomonas spp. in dry aged beef, was expected according to previous studies where the levels these bacteria significantly changed during ageing (Kim et al., 2021). Pseudomonas spp. counts showed a significant increase $(\mathrm{P}<0.01)$ reaching in control samples values up to 8.5 $\log \mathrm{CFU} / \mathrm{g}$ and in treated samples up to 7 $\log$ CFU/g: significantly lower values found in the samples maintained in seawater if compared to control $(\mathrm{P}<0.05)$, considering the whole period. Considering Enterobacteriaceae, concentrations at t0 were below the detection limit (2 log $\mathrm{CFU} / \mathrm{g}$ ); the counts showed a significant increase followed by a stabilization, reaching values above $6 \mathrm{Log} \mathrm{CFU} / \mathrm{g}$ in control samples and close to $5 \mathrm{Log} \mathrm{CFU} / \mathrm{g}$ in treated samples: significantly lower values were found in the samples maintained in seawater if compared to control ( $\mathrm{P}<0.05)$, considering the whole period. The count of halotolerant bacteria at t0 was close to $5 \log$ $\mathrm{CFU} / \mathrm{g}$; these counts showed a significant increase from to to $\mathrm{t} 5(\mathrm{P}<0.01)$ reaching values around 7.30-7.40 $\log \mathrm{CFU} / \mathrm{g}$ without significantly differences between control and treated samples in the whole period. Yeasts showed a very limited increase from t0 (from $3.85 \log \mathrm{CFU} / \mathrm{g}$ reaching loads above $4 \log \mathrm{CFU} / \mathrm{g}$ ) but no significant differences were detected among the two series. Moulds were enumerable at to and t5 but always below $4 \log \mathrm{CFU} / \mathrm{g}$; at the end of the trial moulds resulted to be below the detection limit (3 log TFU/g).

The analyses of combined results showed a general inhibitory effect of marine water on the microbial concentration of meat surface. A potential effect of microbial dilution by the water can be hypothesized, but the absence of evident differences between the two series in the counts of halotolerant bacteria highlights the real inhibitory effect of salt rather than the effect of the dilution.

\section{Chemical-physical analyses}

The salt concentration was calculated only on the treated samples, to verify the grade of salt adsorption by meat. The results showed a constant rate of salt (from 1.5 to $1.7 \%$ ) from t5 without significant improvements during the course of the treatment; the salt fraction dissolved in the aqueous phase of the product (active salt fraction) grows moderately during the test. Considering moisture content, from a value of 68.8 at $\mathrm{t} 0$, between $\mathrm{t} 0$ and $\mathrm{t} 5$, an increase in the products maintained in purified sea water was observed, reaching $74.4 \%$ : in the second half of the experiment however, this difference was no more evident and the values of the two series appeared very similar. Calculated WPS was between 2 and 2.4.

$\mathrm{pH}$ values showed a moderate decrease from to to $t 5$, probably in concomitance with the increase of LAB (from t0 5.57 to 5.34 and 5.47 at $\mathrm{t} 5$ in treated and control samples, respectively). After $\mathrm{t} 5, \mathrm{pH}$ remained substantially constant, with control samples that showed higher, but non significantly different, values.

Considering Water holding capacity
(Table 2), a significant increase in the values indicating water retention was observed in both sample series during the first part of the study $(\mathrm{P}<0.01)$ followed by minor variations. This increase was evidenced also in the control series, and it could be justified by meat maturation (excluding a significant dehydration), but it was clear that the meat maintained in purified sea water gained a significantly and consistently greater water retention capacity. This result is presumably linked to the absorption of salt by the meat, which has given greater osmotic strength.

The evolution of the surface colorimetric parameters (Table 2) shows some important differences between the samples maintained in purified sea water and the control samples. The control samples, underwent a gradual modification of the colour (browning) through the trial: this was justified by the previous dry ageing process, as observed by other authors; the colour parameters of aged beef are characterized by a marked variability among the studies; the comparison of the values obtained in our study with those obtained by previous studies (Azevedo Ribeiro et al., 2021; Kim et al., 2016) showed a lower red and yellow index values, thus justifying the brown external aspect. On the other hand, during the test, the exposed surface of the treated meat underwent a partial protein denaturation; the meat therefore was characterized by a lighter greyish colour. Consequently, the brightness index increased significantly $(\mathrm{P}<0.01)$ during the first part of the test in the treated samples, while it remained stable in the control samples, bringing a statistically significant difference between the two

Table 2. Results of water holding capacity, weight loss, colour parameters and Warner-Bratzler shear force in the two series of meat samples: maintained in seawater (treated) and control.

\begin{tabular}{|c|c|c|c|c|c|}
\hline & & t0 & t5 & t7 & t10 \\
\hline WHC (\% meat area/liquid area) & $\begin{array}{l}\mathrm{T}^{\mathrm{a}} \\
\mathrm{C}^{\mathrm{b}}\end{array}$ & $58.2 \pm 12.7$ & $\begin{array}{c}130.1^{\mathrm{a}} \pm 22.5 \\
75.5^{\mathrm{b}} \pm 6.9\end{array}$ & $\begin{array}{c}141.8^{\mathrm{a}} \pm 26.6 \\
71.7^{\mathrm{b}} \pm 5.8\end{array}$ & $\begin{array}{c}127.2^{\mathrm{a}} \pm 13.3 \\
89.3^{\mathrm{b}} \pm 8.2\end{array}$ \\
\hline Cooking loss (\%) & $\begin{array}{l}\mathrm{T} \\
\mathrm{C}\end{array}$ & 13.5 & $\begin{array}{c}12.6 \\
9.4\end{array}$ & $\begin{array}{c}14.7 \\
8.2\end{array}$ & $\begin{array}{l}19.0 \\
12.3\end{array}$ \\
\hline L* (lightness) & $\begin{array}{l}\mathrm{T} \\
\mathrm{C}\end{array}$ & $40.2 \pm 0.6$ & $\begin{array}{l}48.0^{\mathrm{A}} \pm 1.3 \\
41.6^{\mathrm{B}} \pm 0.5\end{array}$ & $\begin{array}{l}53.7^{\mathrm{A}} \pm 2.1 \\
37.9^{\mathrm{B}} \pm 0.9\end{array}$ & $\begin{array}{l}53.8^{\mathrm{A}} \pm 1.8 \\
35.7^{\mathrm{B}} \pm 1.5\end{array}$ \\
\hline$a^{*}$ (red index) & $\begin{array}{l}\mathrm{T}^{\mathrm{b}} \\
\mathrm{C}^{\mathrm{a}}\end{array}$ & $22.3 \pm 1.1$ & $\begin{array}{c}3.3^{\mathrm{B}} \pm 0.5 \\
11.6^{\mathrm{A}} \pm 1.1\end{array}$ & $\begin{array}{c}3.1^{\mathrm{B}} \pm 0.3 \\
14.2^{\mathrm{A}} \pm 1.1\end{array}$ & $\begin{array}{c}7.2^{\mathrm{B}} \pm 1.1 \\
13.2^{\mathrm{A}} \pm 1.3\end{array}$ \\
\hline $\mathrm{b}^{*}$ (yellow index) & $\begin{array}{l}\mathrm{T} \\
\mathrm{C}\end{array}$ & $13.9 \pm 0.6$ & $\begin{array}{c}6.4^{\mathrm{B}} \pm 0.7 \\
11.0^{\mathrm{A}} \pm 0.4\end{array}$ & $\begin{array}{l}5.6^{\mathrm{B}} \pm 0.2 \\
8.4^{\mathrm{A}} \pm 0.8\end{array}$ & $\begin{array}{l}8.7 \pm 0.8 \\
8.4^{\mathrm{b}} \pm 0.5\end{array}$ \\
\hline Hue-angle & $\begin{array}{l}\mathrm{T}^{\mathrm{a}} \\
\mathrm{C}^{\mathrm{b}}\end{array}$ & 31.9 & $\begin{array}{l}62.7 \\
43.5 \\
\end{array}$ & $\begin{array}{l}61.4 \\
30.5 \\
\end{array}$ & $\begin{array}{l}50.3 \\
32.4 \\
\end{array}$ \\
\hline Chroma & $\begin{array}{l}\mathrm{T}^{\mathrm{b}} \\
\mathrm{C}^{\mathrm{a}}\end{array}$ & 26.3 & $\begin{array}{c}7.2 \\
16.0\end{array}$ & $\begin{array}{c}6.4 \\
16.5\end{array}$ & $\begin{array}{l}11.3 \\
15.7\end{array}$ \\
\hline Warner-Bratzler shear force $\left(\mathrm{kgf} / \mathrm{cm}^{2}\right)$ & $\begin{array}{l}\mathrm{T} \\
\mathrm{C}\end{array}$ & $1.9 \pm 0.4$ & $\begin{array}{l}2.2 \pm 0.4 \\
1.9 \pm 0.5\end{array}$ & $\begin{array}{l}1.7^{\mathrm{B}} \pm 0.5 \\
2.4^{\mathrm{A}} \pm 0.7\end{array}$ & $\begin{array}{l}1.5 \pm 0.3 \\
1.6 \pm 0.3\end{array}$ \\
\hline
\end{tabular}

Superscript letters indicate a statistically significant difference between treated and control samples in the whole period (first column) or in the single sampling sessions (subsequent columns): ABsignificant difference $(\mathrm{P}<0.01) ;{ }^{\mathrm{a}, \mathrm{b}}$ significant difference $(\mathrm{P}<0.05)$. 
Table 3. Results obtained from determination of TVBN in control and treated samples.

\begin{tabular}{|c|c|c|c|c|c|}
\hline TVBN & & to & t5 & t7 & t10 \\
\hline $\mathrm{mg} \mathrm{N} / 100 \mathrm{~g}$ & $\begin{array}{l}\mathrm{T}^{\mathrm{a}} \\
\mathrm{C}^{\mathrm{b}}\end{array}$ & $18.11 \pm 0.75$ & $\begin{array}{c}8.98^{\mathrm{b}} \pm 1.01 \\
18.45^{\mathrm{a}} \pm 2.72\end{array}$ & $\begin{array}{c}9.78^{\mathrm{b}} \pm 0.47 \\
16.90^{\mathrm{a}} \pm 2.57\end{array}$ & $\begin{array}{l}11.06^{\mathrm{B}} \pm 1.81 \\
21.09^{\mathrm{A}} \pm 1.74\end{array}$ \\
\hline
\end{tabular}

Superscript letters indicate a statistically significant difference between treated and control samples in the whole period (first column) or in the single sampling sessions (subsequent columns): ${ }^{\mathrm{AB}}$ significant difference $(\mathrm{P}<0.01)$; a, significant difference $(\mathrm{P}<0.05)$.

data series $(\mathrm{P}<0.01)$; the red and yellow indices decreased in both series, although significantly lower values $(\mathrm{P}<0.01)$ were detected in the treated series (colour of "cooked" meat). The hue values were lower in the treated samples, as well as the Chroma values, the colour saturation index $(\mathrm{P}<0.05$ in both cases in the whole period considered).

The cooking loss was generally very limited (Table 2), lower if compared to previous studies performed on dry aged beef, where cooking loss was around 20\% (Da Silva Bernardo et al., 2021; Kilgannon et al., 2019; Kim et al., 2016). The control samples showed basically a decrease in cooking loss up to $\mathrm{t} 7$, due to the progressive loss of liquids resulting from the evaporation during refrigeration. The treated samples showed higher values if compared to control samples, due to the greater amount of water present in the raw meat after the treatment.

Considering tenderness, evaluated by the measurement of Warner-Bratzler shear force (Table 2), the values obtained were very low, indicating a high degree of tenderness of the meat used; in fact, all the recorded values constantly placed the samples in the category of "very tender" meat $(\leq 2.6$ $\mathrm{kgf} / \mathrm{cm}^{2}$ ) (Belew et al., 2003), probably thanks to the action of proteolytic enzymes which took place during maturation and storage. Previous studies (Da Silva Bernardo et al., 2021; Kilgannon et al., 2019) showed higher values (2.7-3.7 $\mathrm{kgf} / \mathrm{cm}^{2}$ ). Even if during the first part of the experiment no significant changes were noticed, in the second part a tenderization of the treated meat was observed, even if not very marked. Although without a significant trend, the samples subjected to immersion in seawater showed lower values if compared with the control samples.

Finally, considering TVBN (Table 3), a decrease in treated samples was observed between $t 0$ and $t 5$, probably indicating that the treatment of immersion in purified seawater has partially removed the volatile basic nitrogen from the surface of the meat. The values of the control series do not differ much from the value measured at 0 .

\section{Conclusions}

The use of purified sea water for the maturation of beef has led to a modification of some chemical-physical parameters, such as the appearance of cooked meat, a more acidic $\mathrm{pH}$ and greater moisture retained and loss during cooking; in addition, an improvement in the microbiological parameters was also revealed. A partial effect on tenderness was also described at $\mathrm{t} 7$ : based on these results the maintenance of meat in purified seawater may be suggested as optimal time treatment.

The treatment evaluated had an overall positive effect on meat hygiene and quality and can be considered an improvement of meat maturation technique. Further consumer preference test should be also conducted for the evaluation of the economic impact of the treatment.

\section{References}

AOAC, 1990. Official methods of analysis of the Association of Official Analytical Chemists. $15^{\text {th }}$ ed. AOAC, Arlington, TX, USA.

Azevedo Ribeiro, F, Lau, SK, Pflanzer, SB, Subbia, J, Calkins, CR, 2021.Color and lipid stability of dry aged beef during retail display. Meat Sci 171:108274.

Belew JB, Brooks JC, McKenna DR, Savell JW, 2003. Warner-Bratzler shear evaluations of 40 bovine muscles. Meat Sci 64:507-12.

Boleman SJ, Boleman SL, Miller RK, Taylor JF, Cross HR, Wheeler TL, Koohmaraie M, Shackleford SD, Miller MF, West RL, Johnson DD, Savell JW, 1997. Consumer evaluation of beef of known categories of tenderness. J Anim Sci 75:1521-4.

Brooks JC, Belew JB, Griffin BD, Gwartney DL, Hale DS, Henning WR, Johnson DD, Morgan JB, Parrish FC Jr, Reagan JO, Savell JW, 2000. National beef tenderness survey-1998. J Anim Sci 78:1852-60.

Cheng Q, Sun D-W, 2008. Factors affecting the Water Holding Capacity of red meat products: A review of recent research advances. Crit Rev Food Sci 48:137-59.
CIE (1976): Colourimetry: Official recommendations of the international commission on illumination. Publication CIE No. 15 (E-1.3.1). Boreau Central de la Commission Internationale De L'Eclairage, Paris.

Commission Regulation (EC) No 2074/2005. OJ L338: 27-42, 22/12/2005.

Da Silva Bernardo AP, Muniz Da Silva AC, Marinelli Saraiva Ferreira F, Da Silva Do Nascimento M, Bertelli Pflanzer S, 2020. The effects of time and relative humidity on dry-aged beef: Traditional versus special bag. FSTI 27:626-34.

Grau R, Hamm R, 1956. Die Bestimmung der Wasserbindung des Fleisches mittels der Pre-Bmethode. Fleischwirtsch 8:733-4.

Honikel KO, 1998. Reference methods for the assessment of physical characteristics of meat. Meat Sci 49:447-57.

International Organization for Standardization (ISO), 1998. Microbiology of food and animal feeding stuffs-Horizontal methods for the enumeration of mesophilic Lactic Acid Bacteria-colony-count technique at 30 degrees C; ISO 15214:1998. ISO, Geneva, Switzerland.

International Organization for Standardization (ISO), 2008. Microbiology of food and animal feeding stuffs-horizontal methods for the enumeration of yeasts and moulds-Part 1: colony count technique in products with water activity greater than 0,95 ; ISO 21527-1:2008. ISO, Geneva, Switzerland.

International Organization for Standardization (ISO), 2013. Microbiology of the food chainHorizontal method for the enumeration of microorganisms-Part 1: colony count at 30 degrees by the pour plate technique; ISO 4833-1:2013. ISO, Geneva, Switzerland.

International Organization for Standardization (ISO), 2017. Microbiology of food and animal feeding stuffs-Horizontal methods for the detection and enumeration of Enterobacteriaceae-Part 2: colonycount method; ISO 21528-2:2017. ISO, 
Geneva, Switzerland.

Kilgannon AK, Holman BWB, Mawson J, Campbell M, Collins D, Hopkins DL, 2019. The effect of different temperature-time combinations when ageing beef: Sensory quality traits and microbial loads. Meat Sci 150:23-32.

Kim, S, Kim, J-C, Park, S, Kim, J, Yoon, Y, Lee, H, 2021. Identification of microbial flora in dry aged beef to evaluate the rancidity during dry aging. Processes 9:2049.

Kim, YHB, Kemp, R, Samuelsson, LM, 2016. Effects of dry-aging on meat quality attributes and metabolite profiles of beef loins. Meat Sci 111:168-76.

Koohmaraie M, 1996. Biochemical factors regulating the toughening and tenderization processes of meat. Meat Sci 43:S193-201.
Koohmaraie M, Kent MP, Shackelford S, Veiseth E, Wheeler TL, 2002. Meat tenderness and muscle growth: is there any relationship? Meat Sci 62:345-352.

Lawrie RA, 1974. Meat science. Pergamon Press, Oxford, UK.

Lusk JJ, Fox JA, Schroeder TC, Mintert J, Koohmaraie M, 2001. In-store valuation of steak tenderness. Am J Agr Econ 83:539-550.

Lusk JJ. Fox T, Schroeder J, Mintert, Koohmaraie M, 1999. "Will consumers pay for guaranteed tender steak?" Research Bulletin 3-99, Research Institute on Livestock Pricing, Agricultural and Applied Economics, Virginia Tech., Blacksburg, Virginia, USA.

Pearson D, 1973. Laboratory Techniques in Food Analysis. Butterworths \& Co.
Publishers Ltd., London, UK.

Shackelford SD, Wheeler TL, Meade MK, Reagan JO, Byrnes BL, Koohmaraie M, 2001. Consumer impressions of tender select beef. J Anim Sci 79:2605-14.

Smith, GC, Carpenter ZL, 1974. Eating quality of animal products and their fat content. Proceedings of the Symposium on Changing the fat content and composition of animal products. National Academy of Sciences, Washington, D.C.

Wheeler, TL, Shackelford, SD, Koohmaraie, M, 1974. Tenderness classification of beef: III. Effect of the interaction between end point temperature and tenderness on Warner-Bratzler sheer force of beef longissimus. J Anim Sci 77:400-7. 